\title{
MICROINVASIVE CARCINOMA INITTIALY LABELED AS IN SITU
}

Ruffo Freitas-Junior ${ }^{1}$, Nayara A. F. Lemos², Nilceana M. A. Freitas³ ${ }^{3}$ Marise A. R. Moreira ${ }^{4}$, Edésio Martins², José Carlos de Oliveira ${ }^{5}$, Carleane M. B. Silva ${ }^{5}$

${ }^{1}$ Breast Program, Universidade Federal de Goiás (UFG) - Goiânia (GO), Brazil.

${ }^{2}$ Health Science Post-graduate Program of the Medical College, UFG - Goiânia (GO), Brazil.

${ }^{3}$ Department of Radiotherapy, Araújo-Jorge Hospital, Association for the Combat of Cancer - Goiânia (GO), Brazil.

${ }^{4}$ Department of Medicine, UFG - Goiânia (GO), Brazil.

${ }^{5}$ Goiânia Population-Based Cancer Registry - Goiânia (GO), Brazil.

Carcinoma microinvasors are frequently found in the records of ductal carcinoma in situ (DCIS) cases, a factor that may favor non-effective treatment. Survival differs in cases of microinvasion due to the possibility of metastasis. Purpose: was to characterize cases of microinvasive carcinoma transcribed as in situ and subsequent comparison of survival of these cases in relation to cases of DCIS. Methods: We used a secondary database of the Registry of Cancer Population Base of Goiânia and data of the city hall of that city. Results: The mean size of the microinvasive lesions associated with DCIS was $1.3 \mathrm{~cm}$, with foci of invasion $<1.0 \mathrm{~mm}$, the majority of the positivity for estrogen and progesterone receptors corresponded to $28.6 \%$ and for HER2 14,3\%. In addition, $33 \%$ of these cases had impaired margins. Conclusion: attention different from DCIS should be given to microinvasive carcinoma with regard to registration and diagnosis. 